\title{
Simeprevir with pegylated interferon alfa $2 a$ plus ribavirin for treatment of hepatitis $C$ virus genotype 1 in patients with HIV: a meta-analysis and historical comparison
}

\author{
Frank Andersohn ${ }^{1,2^{*}}$, Anne-Kathrin Claes $^{3}$, Werner Kulp ${ }^{3}$, Jörg Mahlich ${ }^{4,5}$ and Jürgen Kurt Rockstroh ${ }^{6}$
}

\begin{abstract}
Background: About one third of patients infected with human immunodeficiency virus (HIV) also have chronic hepatitis due to hepatitis $\mathrm{C}$ virus (HCV). HCV therapy with simeprevir, pegylated interferon alfa (PegIFNa) and ribavirin (RBV) have been shown to be superior to PegIFNa + RBV alone in non-HIV patients, but no randomized trials in patients with HCV genotype 1 (HCV-1) / HIV coinfection are available.
\end{abstract}

Methods: This was a historical comparison of study C212 (simeprevir + PeglFNa-2a + RBV in patients with HCV-1/ HIV coinfection) with studies in which HCV-1/HIV coinfected patients were treated with PegIFNa-2a + RBV alone. A systematic literature search was performed to identify eligible studies. Efficacy and safety results of PeglFNa-2a + RBV studies were combined in random- and fixed-effects inverse-variance weighted meta-analyses of proportions using the Freeman-Tukey double arcsin transformation method, and compared with the results of study C212.

Results: The literature search revealed a total of 2392 records, with 206 articles selected for full-text review. Finally, 11 relevant articles reporting on 12 relevant study groups were included. Results on sustained virologic response 24 weeks after end of treatment (SVR24) were available from all 12 study groups. Pooled SVR24 for PeglFNa$2 a+$ RBV from the random-effects meta-analysis was $28.2 \%$ (95\% Cl $23.8 \%$ to $32.9 \%$ ). The comparison between study C212 (SVR24 $=72.6 \% ; 95 \%$ Cl $63.1 \%$ to $80.9 \%$ ) revealed substantial superiority of simeprevir + PeglFNa-2a + RBV compared to PegIFNa-2a + RBV alone, with an absolute risk difference of $45 \%$ (95 \% Cl 34 to 55). This finding was robust in a sensitivity analysis that only included historical studies with a planned treatment duration of at least 48 weeks and the same RBV dose as in study C212. No increases in the frequency of important adverse event categories including anemia were identified, but these analyses were limited by the low number of studies.

Conclusion: This historical comparison provides first systematic evidence for the superiority of simeprevir + PegIFNa$2 a+$ RBV compared to PegIFNa-2a + RBV in patients with HCV-1 / HIV coinfection. Given the limitations of the historical comparison for safety endpoints, additional data on the comparative safety of simeprevir in patients with HCV-1 / HIV coinfection would be desirable.

Trial registration: Identifier for study TMC435-TiDP16-C212 (ClinicalTrials.gov): NCT01479868.

Keywords: Chronic hepatitis, Hepatitis C virus, Human immunodeficiency virus, Simeprevir, Pegylated interferon alfa, Ribavirin, Efficacy, Safety, Historical comparison

\footnotetext{
* Correspondence: frank.andersohn@charite.de

${ }^{1}$ Charité - University Medicine Berlin; Institute for Social Medicine,

Epidemiology and Health Economics, 10098 Berlin, Germany

${ }^{2}$ Frank Andersohn Consulting \& Research Services, Mandelstr. 16, 10409

Berlin, Germany

Full list of author information is available at the end of the article
} 


\section{Background}

Chronic hepatitis due to hepatitis $\mathrm{C}$ virus ( $\mathrm{HCV}$ ) is an important comorbidity in people infected with the human immunodeficiency virus (HIV). It has been estimated in US [1] and European [2] studies that approximately one third of patients with HIV are coinfected with HCV. The course of chronic hepatitis due to HCV has been reported to be more severe in people with HIV, leading to an increased risk of decompensated liver disease, histological cirrhosis [3, 4] and death [4]. The increased duration of survival in people with HIV due to the efficacy of highly active antiretroviral therapy (HAART) has additionally augmented the importance of successful HCV treatment.

A combination therapy of pegylated interferon alfa (PegIFN $)$ plus ribavirin (RBV) has been the cornerstone of $\mathrm{HCV}$ treatment for several years. During the last years, several new direct acting antivirals have been developed or are currently in phase II or phase III studies. Three NS3/4A serine protease inhibitors (boceprevir, telaprevir and simeprevir) have been licensed for the treatment of $\mathrm{HCV}$ genotype $1(\mathrm{HCV}-1)$ infection in combination with PegIFN $\alpha+R B V$. In individuals without HIV infection, adding these drugs to PegIFN $\alpha+$ RBV has substantially increased $\mathrm{HCV}$ eradication, measured by sustained virologic response $(\mathrm{SVR}=$ undetectable $\mathrm{HCV}$ RNA 12 (SVR12) or 24 (SVR24) weeks after completion of treatment) [5]. One randomized controlled trial (RCT) evaluating the efficacy and safety of these drugs in patients with HCV-1/HIV coinfection is available for boceprevir [6] and telaprevir [7], respectively. However, for simeprevir which has been reported to have advantages over boceprevir and telaprevir in terms of pill-burden and adverse event (AE) profile, only a single-arm trial (study identifier TMC435-TiDP16C212 = „study C212“) is available [8]. A systematic comparison between simeprevir + PegIFN $\alpha-2 \mathrm{a}+\mathrm{RBV}$ vs. PegIFN $\alpha-2 \mathrm{a}+\mathrm{RBV}$ alone in patients with $\mathrm{HCV}-1 / \mathrm{HIV}$ coinfection is, however, lacking. Aim of this study was to compare the main results from study C212 (simeprevir + PegIFN $\alpha-2 a+R B V)$ with data from earlier (historical) studies that evaluated the efficacy and safety of PegIFN $\alpha-$ $2 \mathrm{a}+\mathrm{RBV}$ in patients with $\mathrm{HCV}-1 / \mathrm{HIV}$ coinfection. Focus of this comparison was SVR, in addition data on important AE categories (e.g. total AEs; total SAEs; total AEs leading to discontinuation) were also extracted for the comparison.

\section{Methods}

\section{Study design}

This is a historical comparison (also called non-adjusted indirect comparison) which compares study C212 (simeprevir + PegIFNo-2a + RBV in patients with chronic HCV$1 / \mathrm{HIV}$ coinfection) with studies and/or study groups in which $\mathrm{HCV}-1 / \mathrm{HIV}$ coinfected patients were treated with PegIFN $\alpha-2 a+R B V$ only. The conduct of the historical comparison consisted of the following steps: 1) a systematic literature search and selection of relevant studies; 2) a meta-analysis of proportions; 3 ) a re-transformation of the meta-analysis results (i.e. proportions and $95 \%$ confidence intervals (CI)) into corresponding numerator / denominator pairs; and 4) a historical comparison of the results from study $\mathrm{C} 212$ with historical results from the metaanalysis. The systematic review and meta-analysis was performed and reported in accordance with the Preferred Reporting Items for Systematic Reviews and MetaAnalyses (PRISMA)-Statement [9].

\section{Eligibility criteria}

To increase the validity of the historical comparison inclusion and exclusion criteria were aligned to the study design of C212. Study C212 (ClinicalTrials.gov identifier NCT01479868) is an open-label, single arm clinical study to evaluate the safety, tolerability and efficacy of simeprevir along with PegIFN $\alpha-2 \mathrm{a}$ and RBV triple therapy in adult chronic HCV genotype-1 infected patients who were coinfected with the human immunodeficiency virus-type 1 (HIV-1). The study included HCV treatment-naïve patients who never received medication for the treatment of $\mathrm{HCV}$, as well as relapsers and non-responders to prior $\mathrm{HCV}$ therapy. All patients received Simeprevir $150 \mathrm{mg}$ q.d. for 12 weeks, in combination with PegIFNo-2a (180 $\mu$ g per week) and RBV (1000 mg b.i.d. for patients with a body weight $<75 \mathrm{~kg}$; and $1200 \mathrm{mg}$ b.i.d. for patients with a body weight $\geq 75 \mathrm{~kg}$ ). The duration of therapy with PegIFN $\alpha-2 a$ and RBV was 24 or 48 weeks, depending on virologic response: A shortened duration of 24 weeks was used for treatment-naïe patients or relapsers who had a HCV-RNA $<25 \mathrm{IU} / \mathrm{mL}$ at week 4 (detectable or nondetectable) and at week 12 (non-detectable); all other patients received 48 weeks of treatment.

To be included in the meta-analysis studies had to fulfill all of the following inclusion criteria: 1) Adult patients with chronic HCV genotype-1 and HIV coinfection. Studies with patients who had chronic hepatitis $\mathrm{C}$ due to other $\mathrm{HCV}$ genotypes were only included, if the publication included HCV-1 stratified results for at least one of the endpoints of interest. 2) Treatment with PegIFN $\alpha-2 a$ and RBV for at least 12 weeks (for safety endpoint) or 24 weeks (for SVR). Studies involving PegIFN $\alpha-2 b$ were excluded due to potential pharmacodynamics differences between PegIFN $\alpha-2 a$ and PegIFN $\alpha-2 b .3)$ Results are presented for at least one of the pre-defined endpoints of interest: Proportion of patients with SVR 12 or 24 weeks after end of therapy; proportion of patients with at least one $\mathrm{AE}$; proportion of patients with at least one serious AE; proportion of patients who interrupted treatment due to an AE; proportion of patients with AEs of special interest (i.e. anemia; psychiatric disorders; infections; increase of blood bilirubin levels; adverse cutaneous 
events). 4) Study was a RCT or another (e.g. single-arm) clinical trial, or an observational cohort study. 5) Study results were available from a full publication in a scientific journal or a study report (i.e. meeting abstracts and/or scientific poster presentations were not included). Studies were excluded, if the population was highly selected (e.g. selected by previous response/non-response to PegIFNa and/or RBV; selected by comorbidity such as hemophilia; selected by concomitant treatment such as a specific HIV therapy) or if the publication presented a case series or a study with a very low number of participants (i.e. $\mathrm{N}<10$ patients in the relevant analyses). For studies with more than one study arm (e.g. RCTs), the inclusion of two or more study groups were possible as long as they fulfilled the eligibility criteria.

\section{Systematic literature search and data extraction}

The systematic search for relevant publications were performed at July 24, 2014, using the electronic databases Medline, EMBASE (Excerpta Medica Database) and the Cochrane Central Register of Controlled Trials. The search included terms for HCV and HIV, in combination with intervention terms for PegIFN $\alpha-2 a$ and RBV. The search was limited "human" and to English or German language. The full electronic search strategy for Medline is included in an online appendix as an example (Additional file 1 - electronic search strategy for Medline). Selection of relevant studies or study groups were performed independently by two authors; potential discrepancies were resolved by discussion. For all included studies, pre-defined study design characteristics; characteristics of the study populations; and results of the studies (for relevant endpoints) were extracted.

\section{Statistical analysis}

As all endpoints of interest were proportions (i.e. number of patients with a certain event divided by the total number of patients), an inverse-variance weighted metaanalysis of proportions using the Freeman-Tukey double arcsin transformation method $[10,11]$ was performed for each endpoint of interest. Both fixed- and randomeffects meta-analyses were performed and heterogeneity was evaluated based on Cochran's Q; $\mathrm{I}^{2}$; and the test for heterogeneity. To allow a direct comparison with study $\mathrm{C} 212$, the meta-analytical proportions including their $95 \% \mathrm{CI}$ were re-transformed into the best-fitting corresponding numerator/denominator pair using iteration. The iteration identified the numerator/denominator pair for which the width of the $95 \%$ binomial (Wilson score) $\mathrm{CI}$ is most similar to the width of the meta-analytical $95 \%$ CI. For example, for a meta-analytical proportion of 0.277 with a $95 \%$ CI of 0.253 to 0.302 , the best-fit numerator/denominator pair is 364/1313 (as it corresponds to a proportion of 0.277 with a $95 \%$ Wilson CI of 0.253 to 0.302$)$. Using these numerator/denominator pairs, relative risks as well as absolute risk differences of simeprevir + PegIFNo-2a + RBV (from study C212) vs. PegIFN $\alpha-2 a+$ RBV (from the meta-analyses) were calculated for all endpoints of interest. If for an endpoint results from not more than one historical study were available, no meta-analysis was performed for that endpoint and the numerator/denominator pair from the single historical study was used for the comparison. To evaluate the potential impact of the duration of treatment and the daily dose of RBV on SVR24, a pre-planned sensitivity analysis was performed. This analysis included only studies with a treatment duration of 48 weeks for PegIFN $\alpha-2 a+$ RBV and that used RBV in the same weight-based daily dose as in study C212. To allow a full evaluation of the available evidence a historical comparison of study C212 and each of the identified studies / study arms was performed in addition to the comparison with the results from meta analyses. All analyses were performed with SAS 9.3 (SAS Institute, Cary NC).

\section{Results \\ Literature search}

The literature search in Medline, EMBASE, and the Cochrane Central Register of Controlled Trials revealed a total of 2392 records. After exclusion of 554 duplicates, a total of 1838 records remained for review. $N=1632$ records were excluded based on title and/or abstract, leaving 206 articles for full-text review. From these publications, $N=195$ articles were excluded while 11 relevant articles [12-22] were included (see Fig. 1 for details on the literature selection process). One of the 11 studies reported on two relevant study groups, while 10 had one relevant study arm, resulting in a total of 12 relevant study groups.

\section{Characteristics of included studies}

The comparability between the included studies and study C212 with respect to important characteristics of study design and patient population was acceptable (see Table 1 for details). Differences were noted for the duration of treatment with PegIFN $\alpha-2 a+R B V$; the daily dose of RBV; and the inclusion/exclusion of relapsers and/or non-responders to previous PegIFN $\alpha$-based HCV therapy. For the following endpoints of interest, results from at least one of the identified historical studies were available: Proportion of patients with SVR after 24 weeks $(N=12$ study groups); proportion of patients with at least one $\mathrm{AE}(N=2$ study groups); proportion of patients with at least one serious $\mathrm{AE}(N=2$ study groups); proportion of patients who interrupted treatment due to an AE ( $N=1$ study group); proportion of patients with anemia ( $N=3$ study groups); and proportion of patients with psychiatric disorders ( $N=1$ study group). No historical comparisons were possible for SVR after 12 weeks and for the AE categories infections; increase of blood 


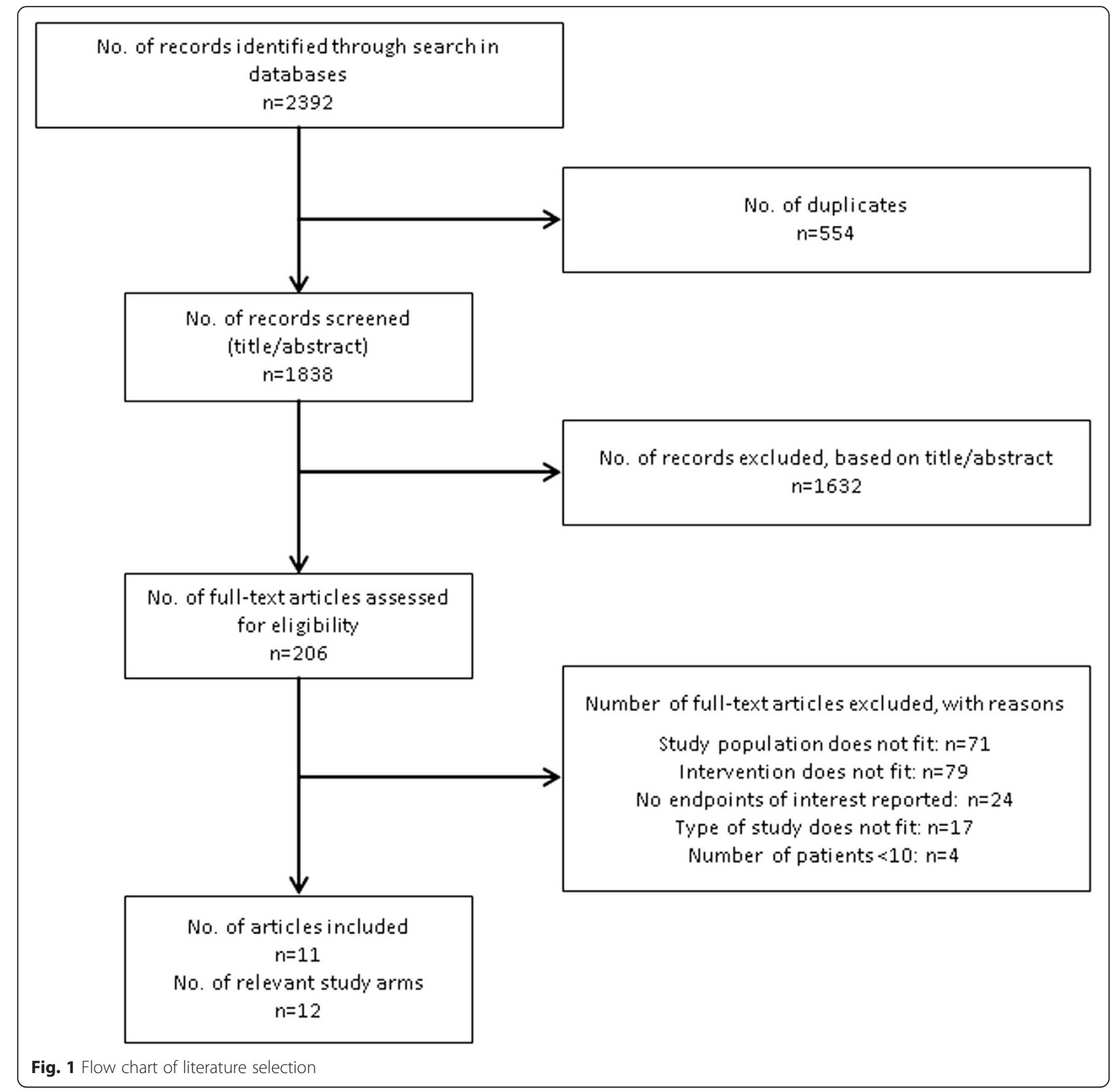

bilirubin levels; and adverse cutaneous events. All included historical studies reported on SVR24, while only a minor proportion reported on AEs. This was due to the fact that only results for patients with $\mathrm{HCV}-1$ infection were of relevance for the historical comparison. Publications on studies that also included patients infected with other HCV genotypes, however, reported HCV-1 stratified results only for SVR but not for AEs.

\section{Historical comparison - efficacy}

From all included 12 study groups, results on SVR24 were available. The meta-analysis indicated heterogeneity between PegIFN $\alpha-2 a+R B V$ study groups $\left(I^{2}=\right.$
$65.3 \% ; \mathrm{p}<0.001)$. However, the results of the fixedeffects model (SVR24 $=27.7 \%$; $95 \%$ CI 25.3 to $30.2 \%$ ) and the random-effects model (SVR24= $28.2 \%$; 95 \% CI 23.8 \% to $32.9 \%$ - see Fig. 2) were similar. After re-transformation of proportions into estimated numerator/denominator pairs (364/1313 for the fixed effects model, and 104/369 for the random effects model; see Additional file 2 for details), the comparison between study C212 (SVR24=72.6 \%; $95 \%$ CI $63.1 \%$ to $80.9 \%$ ) and the meta-analyses results revealed substantial superiority of simeprevir + PegIFN $\alpha-2 a+R B V$ compared to PegIFN $\alpha-2 a+R B V$ alone (see Table 2), with a relative risk of 2.58 
Table 1 Characteristics of included studies

\begin{tabular}{|c|c|c|c|c|c|c|c|c|c|c|c|c|}
\hline Study & $\begin{array}{l}\text { Study } \\
\text { period }\end{array}$ & $\begin{array}{l}\text { Study } \\
\text { region }\end{array}$ & $\begin{array}{l}\text { Multi- } \\
\text { center } \\
\text { study? }\end{array}$ & $\begin{array}{l}\text { Study } \\
\text { design }\end{array}$ & $\begin{array}{l}\text { Relapser/Non- } \\
\text { responder } \\
\text { included? }\end{array}$ & $\begin{array}{l}\text { Patients } \\
\text { on HIV } \\
\text { therapy }\end{array}$ & Planned duration of treatment & Ribavirin dose per day & $\begin{array}{l}\text { Number of } \\
\text { patients }^{\mathrm{a}}\end{array}$ & $\begin{array}{l}\text { Mean/ } \\
\text { median age } \\
\text { (years) }\end{array}$ & $\begin{array}{l}\text { Males } \\
(\%)\end{array}$ & $\begin{array}{l}\text { Patients } \\
\text { with liver } \\
\text { cirrhosis (\%) }\end{array}$ \\
\hline \multirow[t]{2}{*}{ Study C212 } & \multirow[t]{2}{*}{$\begin{array}{l}2011- \\
2013\end{array}$} & \multirow[t]{2}{*}{$\begin{array}{l}\text { Multi- } \\
\text { national }\end{array}$} & \multirow[t]{2}{*}{ Yes } & \multirow[t]{2}{*}{ Single-arm } & \multirow[t]{2}{*}{ yes } & \multirow[t]{2}{*}{$85 \%$} & $\begin{array}{l}\text { Treatment-naïve patients + } \\
\text { relapsers with EVR at week 4/12: } \\
24 \text { weeks }\end{array}$ & \multirow[t]{2}{*}{$\begin{array}{l}1000 \mathrm{mg} / 1200 \mathrm{mg} \\
\text { (w.a.) }\end{array}$} & \multirow[t]{2}{*}{$N=106$} & \multirow[t]{2}{*}{47 years } & \multirow[t]{2}{*}{$85 \%$} & \multirow[t]{2}{*}{$13 \%$} \\
\hline & & & & & & & All other patients: 48 weeks & & & & & \\
\hline \multirow[t]{2}{*}{$\begin{array}{l}\text { Chung } 2004 \\
{[12]}\end{array}$} & \multirow[t]{2}{*}{$\begin{array}{l}2000- \\
2002\end{array}$} & \multirow[t]{2}{*}{ US } & \multirow[t]{2}{*}{ Yes } & \multirow[t]{2}{*}{$\begin{array}{l}\text { RCT (not } \\
\text { blinded) }\end{array}$} & \multirow[t]{2}{*}{ no } & \multirow[t]{2}{*}{$82 \%$} & $\begin{array}{l}\text { Patients without response in } \\
\text { week 24: } 24 \text { weeks }\end{array}$ & \multirow{2}{*}{$\begin{array}{l}600 \text { mg (week 1-4); } 800 \\
\text { mg (week 5-8); } 1000 \text { mg } \\
\text { (week >8) }\end{array}$} & \multirow[t]{2}{*}{$N=51$} & \multirow[t]{2}{*}{45 years } & \multirow[t]{2}{*}{$82 \%$} & \multirow[t]{2}{*}{$10 \%$} \\
\hline & & & & & & & $\begin{array}{l}\text { Patients with response in week } \\
\text { 24: } 48 \text { weeks }\end{array}$ & & & & & \\
\hline $\begin{array}{l}\text { Dahari } 2010 \\
\text { [13] }\end{array}$ & n.r. & Brazil & No & Single-arm & n.r. & $88 \%$ & 48 weeks & $\begin{array}{l}11 \mathrm{mg} / \mathrm{kg} \text { body } \\
\text { weight }\end{array}$ & $N=13$ & 41 years & $88 \%$ & $15 \%$ \\
\hline \multirow[t]{2}{*}{$\begin{array}{l}\text { Fuster } 2006 \\
{[14]}\end{array}$} & \multirow[t]{2}{*}{$\begin{array}{l}2001- \\
2002\end{array}$} & \multirow[t]{2}{*}{ Spain } & \multirow[t]{2}{*}{ Yes } & \multirow[t]{2}{*}{$\begin{array}{l}\text { RCT (not } \\
\text { blinded) }\end{array}$} & \multirow[t]{2}{*}{ no } & \multirow[t]{2}{*}{$75 \%$} & $\begin{array}{l}\text { Patients with EVR in week 12: } \\
48 \text { weeks }\end{array}$ & \multirow[t]{2}{*}{$800 \mathrm{mg}$} & \multirow[t]{2}{*}{$N=51$} & \multirow[t]{2}{*}{39 years } & \multirow[t]{2}{*}{$75 \%$} & $39 \%{ }^{b}$ \\
\hline & & & & & & & $\begin{array}{l}\text { Patients without EVR in week } \\
\text { 12: } 48 \text { weeks or } 72 \text { weeks } \\
\text { (randomized) }\end{array}$ & & & & & \\
\hline $\begin{array}{l}\text { Mandorfer } \\
2014[22]\end{array}$ & n.r. & Austria & Yes & Single-arm & no & $73 \%$ & $\begin{array}{l}\text { Patients with RVR in week } 4 \text { : } \\
48 \text { weeks }\end{array}$ & $\begin{array}{l}1000 \mathrm{mg} \text { to } 1200 \\
\mathrm{mg} \text { for } 12 \text { weeks; } 800 \mathrm{mg}\end{array}$ & $N=28$ & 37 years & $73 \%$ & $42 \%$ \\
\hline & & & & & & & $\begin{array}{l}\text { Patients without RVR in week } \\
\text { 4: } 72 \text { weeks }\end{array}$ & $\tau$ & & & & \\
\hline $\begin{array}{l}\text { Murphy } \\
2011[15]\end{array}$ & $\begin{array}{l}2004- \\
2007\end{array}$ & US & No & $\begin{array}{l}\text { RCT (not } \\
\text { blinded) }\end{array}$ & n.r. & $90 \%$ & 48 weeks & $\begin{array}{l}1000 \mathrm{mg} / 1200 \mathrm{mg} \\
\text { (w.a.) }\end{array}$ & $N=10$ & 48 years & $90 \%$ & n.r. \\
\hline $\begin{array}{l}\text { Nunez } 2007 \\
{[16]}\end{array}$ & $\begin{array}{l}2003- \\
2006\end{array}$ & Spain & Yes & $\begin{array}{l}\text { Non- } \\
\text { randomized }\end{array}$ & no & $78 \%$ & $\begin{array}{l}\text { Patients without EVR in week } \\
\text { 12: } 12 \text { weeks }\end{array}$ & $\begin{array}{l}1000 \mathrm{mg} / 1200 \mathrm{mg} \\
\text { (w.a.) }\end{array}$ & $N=191$ & 39 years & $77 \%$ & $11 \%$ \\
\hline & & & & & & & $\begin{array}{l}\text { Patients with detectable HCV } \\
\text { in week 24: } 24 \text { weeks }\end{array}$ & & & & & \\
\hline & & & & & & & $\begin{array}{l}\text { All other patients: } 48 \text { weeks } \\
\text { (since August 2004: } 72 \text { weeks) }\end{array}$ & & & & & \\
\hline $\begin{array}{l}\text { Rivero- } \\
\text { Juarez } 2014 \\
{[17]}\end{array}$ & n.r. & Spain & Yes & $\begin{array}{l}\text { Non- } \\
\text { randomized } \\
\text { study }\end{array}$ & no & $92 \%$ & $\begin{array}{l}\text { Treatment according to } 2009 \\
\text { AASLD guidelines ( } 48 \text { weeks; } \\
\text { patients with delayed virologic } \\
\text { response: } 72 \text { weeks) }\end{array}$ & $\begin{array}{l}1000 \mathrm{mg} / 1200 \mathrm{mg} \\
\text { (w.a.) }\end{array}$ & $N=192$ & 42 years & $82 \%$ & $51 \%^{c}$ \\
\hline $\begin{array}{l}\text { Rodriguez- } \\
\text { Torres } 2012 \\
{[21]}\end{array}$ & $\begin{array}{l}2006- \\
2009\end{array}$ & $\begin{array}{l}\text { US, } \\
\text { Spain, } \\
\text { Portugal }\end{array}$ & Yes & $\begin{array}{l}\text { RCT } \\
\text { (blinded) }\end{array}$ & no & $89 \%$ & 48 weeks $^{d}$ & $\begin{array}{l}\text { Treatment group 1: } \\
800 \mathrm{mg}\end{array}$ & $\begin{array}{l}N=135 \\
\text { (group 1) }\end{array}$ & 45 years & $80 \%$ & $12 \%$ \\
\hline
\end{tabular}


Table 1 Characteristics of included studies (Continued)

\begin{tabular}{|c|c|c|c|c|c|c|c|c|c|c|c|c|}
\hline & & & & & & & & & & & & \\
\hline $\begin{array}{l}\text { Torres- } \\
\text { Cornejo } \\
2014 \text { [18] }\end{array}$ & $\begin{array}{l}2004- \\
2011\end{array}$ & Spain & No & $\begin{array}{l}\text { Non- } \\
\text { randomized } \\
\text { study }\end{array}$ & no & $85 \%$ & 48 weeks & $\begin{array}{l}1000 \mathrm{mg} / 1200 \mathrm{mg} \\
\text { (w.a.) }\end{array}$ & $N=135$ & 41 years & $85 \%$ & $39 \%$ \\
\hline $\begin{array}{l}\text { Torriani } \\
2004 \text { [19] }\end{array}$ & $\begin{array}{l}2000- \\
2003\end{array}$ & $\begin{array}{l}\text { Multi- } \\
\text { national }\end{array}$ & Yes & $\begin{array}{l}\mathrm{RCT} \\
\text { (blinded) }\end{array}$ & no & $84 \%$ & 48 weeks & $800 \mathrm{mg}$ & $N=176$ & 40 years & $80 \%$ & $15 \%$ \\
\hline $\begin{array}{l}\text { Tural } 2008 \\
\text { [20] }\end{array}$ & $\begin{array}{l}2003- \\
2005\end{array}$ & Spain & Yes & $\begin{array}{l}\text { Non- } \\
\text { randomized } \\
\text { study }\end{array}$ & n.r. & n.r. & 48 weeks & $\begin{array}{l}1000 \mathrm{mg} / 1200 \mathrm{mg} \\
\text { (w.a.) }\end{array}$ & $N=55$ & 40 years & $67 \%$ & n.r. \\
\hline
\end{tabular}

Only patients with $\mathrm{HCV}-1$ infection

${ }^{\mathrm{b}}$ Bridging fibrosis or fibrosis

${ }^{\mathrm{d}}$ No early stopping rules according to study protocol, but within the discretion of the study physician

EVR early virologic response, RVR rapid virologic response, n.r. not reported, w.a. weight-adapted (1000 mg for body weight $<75 \mathrm{~kg} ; 1200 \mathrm{mg}$ for body weight $\geq 75 \mathrm{~kg}$ ) 


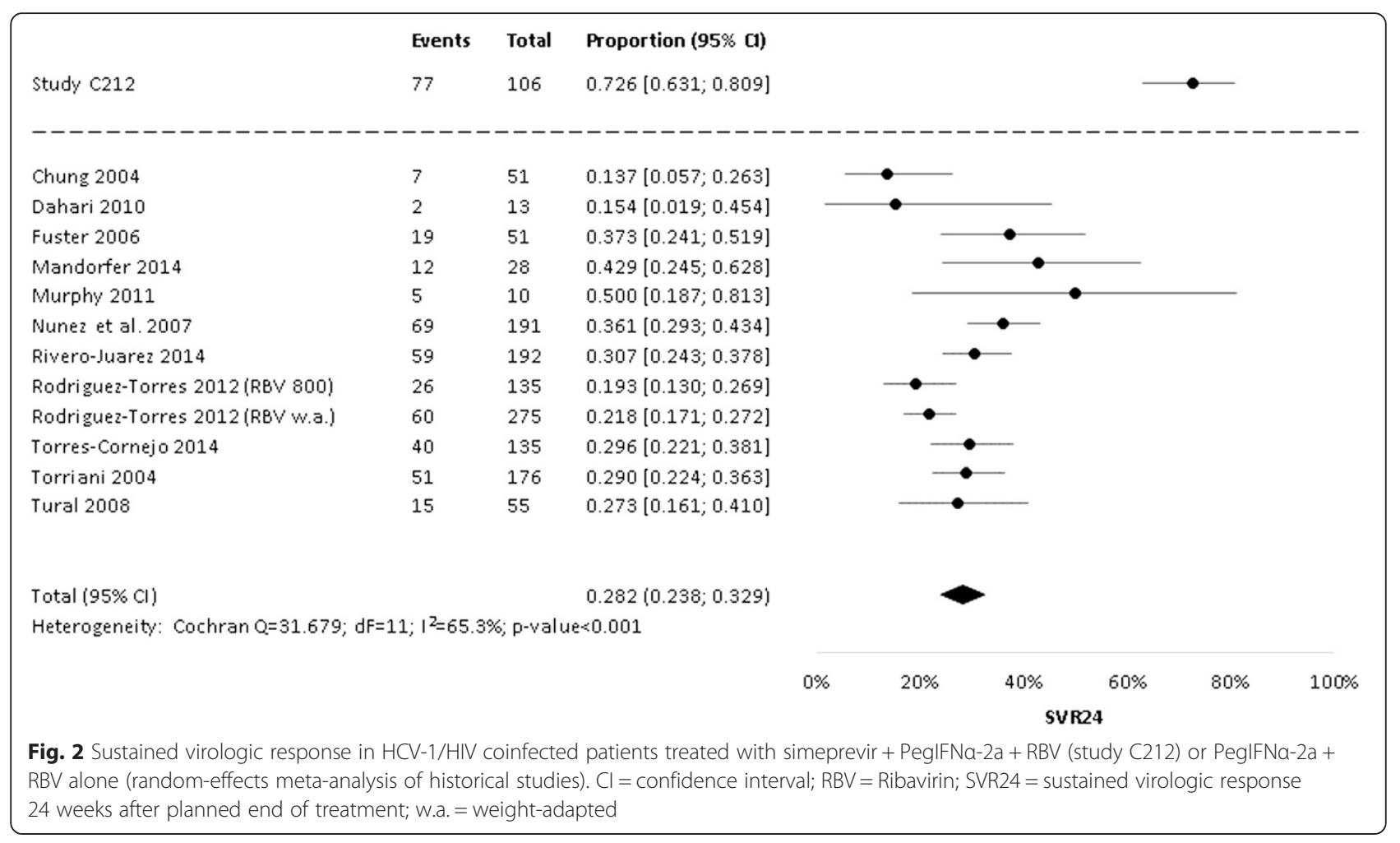

(random effects model) or 2.62 (fixed effects model) and a risk difference of $45 \%$ (both models).

The sensitivity analysis that included only studies $(N=5)$ with at least 48 weeks of treatment duration and weightadapted dosing of RBV revealed similar results (random effects model: $\mathrm{RR}=2.59 ; 95 \% \mathrm{CI} 2.06$ to 3.26 and fixed effects model: $\mathrm{RR}=2.70 ; 95 \% \mathrm{CI} 2.28$ to 3.21 ). A direct comparison between $\mathrm{C} 212$ and the individual historical study groups also showed statistically significant superiority of simeprevir + PegIFN $\alpha-2 \mathrm{a}+\mathrm{RBV}$ for 11 comparisons; for one study [15] the effect estimate was not statistically significant, but this was attributable to the low number of patients included in this study $(N=10)$.

\section{Historical comparison - safety}

The comparison between simeprevir + PegIFN $\alpha-2 a+$ RBV and historical data for PegIFN $\alpha-2 a+$ RBV did not indicate an increase in risk of the $\mathrm{AE}$ categories included

Table 2 Main results of historical comparison (simeprevir + PegIFNa-2a + RBV vs. PegIFNa-2a + RBV)

\begin{tabular}{|c|c|c|c|c|}
\hline & \multicolumn{2}{|c|}{ Number of patients with event/total number of patients (\%) } & \multirow{2}{*}{$\begin{array}{l}\text { Relative risk } \\
(95 \% \mathrm{Cl})\end{array}$} & \multirow{2}{*}{$\begin{array}{l}\text { Risk difference } \\
(95 \% \mathrm{Cl})\end{array}$} \\
\hline & Simeprevir + PegIFNa-2a + RBV & PeglFNa-2a + RBV & & \\
\hline \multicolumn{5}{|l|}{ Efficacy } \\
\hline SVR24 (random effects) & 77/106 (72.6\%) & 104/369 (28.2 \%) & $2.58(2.11 ; 3.15)$ & $0.45(0.34 ; 0.55)$ \\
\hline SVR24 (fixed effects) & & $364 / 1313(27.7 \%)$ & $2.62(2.27 ; 3.03)$ & $0.45(0.36 ; 0.54)$ \\
\hline \multicolumn{5}{|l|}{ Safety } \\
\hline At least one $A E^{a}$ & 103/106 (97.2 \%) & 396/410 (96.6 \%) & $1.01(0.97 ; 1.04)$ & $0.01(-0.04 ; 0.05)$ \\
\hline At least one $S A E^{a}$ & $11 / 106(10.4 \%)$ & $67 / 407(16.5 \%)$ & $0.63(0.35 ; 1.15)$ & $-0.06(-0.14 ; 0.01)$ \\
\hline AEs leading to discontinuation ${ }^{b}$ & $5 / 106(4.7 \%)$ & $21 / 135(15.6 \%)$ & $0.30(0.12 ; 0.78)$ & $-0.11(-0.19 ;-0.03)$ \\
\hline Anemia AEs (random effects) & 35/106 (33.0 \%) & $58 / 202(28.7 \%)$ & $1.15(0.81 ; 1.63)$ & $0.04(-0.07 ; 0.16)$ \\
\hline Anemia AEs (fixed effects) & & 124/418 (29.7 \%) & $1.11(0.82 ; 1.52)$ & $0.03(-0.07 ; 0.14)$ \\
\hline Psychiatric disorders $A E s^{c}$ & 63/106 (59.4 \%) & 3/10 (30.0 \%) & $1.98(0.76 ; 5.17)$ & $0.29(-0.06 ; 0.65)$ \\
\hline
\end{tabular}

${ }^{a}$ No difference between random and fixed effects models

${ }^{\mathrm{b}}$ Results for PegIFNa-2a + RBV from Torres-Cornejo 2014 [18]

${ }^{c}$ Results for PeglFNa-2a + RBV from Murphy 2011 [15]

$C l$ confidence interval, SVR24 sustained virologic response 24 weeks after planned end of treatment, $A E$ adverse event, $S A E$ serious adverse event, $R B V$ ribavirin, PegIFNa-2a peginterferon-alpha- $2 a$ 
(see Table 2). These analyses were limited by the low number of historical studies contributing data.

\section{Discussion}

The historical comparison revealed a substantially higher proportion of patients with SVR with simeprevir + PegIFNo-2a + RBV compared to PegIFNo-2a + RBV alone in patients with HCV-1 and HIV coinfection. The absolute difference in risk was approximately $45 \%$, which corresponds to a number-needed-to treat of 2.2. No increases in risk were observed for the total number of AEs; serious AEs; AEs leading to discontinuation; anemia AEs; or AEs indicating psychiatric disorders.

For patients with chronic hepatitis due to HCV-1 infection but without HIV, results from RCTs comparing simeprevir with placebo in addition to PegIFN $\alpha+$ RBV are available. These trials demonstrated increased SVR with simeprevir, with absolute differences in risk ranging between approx. $30 \%$ for treatment-naïve patients (QUEST-1 [23] and QUEST-2 [24]) and approx. $45 \%$ for relapsers (PROMISE [25]) or non-responders (ASPIRE [26]) after a previous IFN-based therapy. These differences were primarily due to different proportions of patients with SVR in the placebo groups (i.e. Placebo + PegIFN $\alpha+$ RBV) of these trials. While treatment-naïve patients (QUEST-1 and QUEST-2) had a SVR of approx. $50 \%$, relapsers (PROMISE) showed a SVR of $36 \%$, and previous non-responders had a SVR of $23 \%$. In the meta-analysis for the historical comparison, the overall estimate for PegIFNo-2a + RBV in was $28.2 \%$, even though included trials only included treatment-naïve patients or did not report on prior treatment status. This is in line with the fact that response to PegIFN $\alpha-2 a+R B V$ is worse in patients with $\mathrm{HCV} / \mathrm{HIV}$ coinfection, compared to $\mathrm{HCV}$ infection alone [27].

A recent systematic review of the treatment of hepatitis C [27] identified two RCTs that compared boceprevir or telaprevir with placebo (in addition to PegIFN $\alpha+$ $\mathrm{RBV}$ ) in patients with chronic hepatitis $\mathrm{C}$ who were coinfected with HCV and HIV. The study on boceprevir [6] included 99 treatment-naïve patients with $\mathrm{HCV}$ genotype 1 infection and a controlled HIV infection and randomized them 2:1 to boceprevir + PegIFN $\alpha-2 b+R B V$, or to placebo + PegIFN $\alpha-2 b+R B V$. Boceprevir was superior to placebo with respect to SVR24 (absolute difference in risk $33.1 \%$; $95 \%$ CI 13.7-52.5) but was associated with an increased frequency of AEs such as anemia. Treatment discontinuations due to AEs occurred more frequently with boceprevir than with placebo $(20 \%$ vs. $9 \%)$. The proportion of patients with SVR24 in the placebo group (29.4\%) was similar to the proportion of patients with SVR24 in the meta-analysis for the historical comparison $(28.2 \%)$. The telaprevir RCT [7] randomized 64 treatment-naïve patients with
HCV genotype 1 infection and HIV-1 infection to telaprevir or placebo, both in addition to PegIFNa-2a + RBV. Telaprevir was superior to placebo with respect to SVR24, with an absolute difference in risk of $29 \%$ (95\% CI 3-53). The proportion of patients with SVR24 in the placebo group was $45 \%$ (10 out of 22 patients), however this estimate was limited by the rather low number of patients included. Telaprevir was associated with a significantly increased frequency of pruritus (39\% vs. $9 \%$ ), and a non-significant increase in the proportion of patients with at least one serious AE (18\% vs. $9 \%)$.

Compared to simeprevir (1 capsule per day), the pillburden associated with boceprevir or telaprevir is substantially higher (12 capsules or 6 tablets per day, respectively). In addition, simeprevir seems to have some advantages related to AEs. The frequency of anemia was similar in the simeprevir and the placebo group in four RCTs that included non-HIV patients [23-26]. The historical comparison also did not indicate a higher frequency of anemia in patients treated with simeprevir + PegIFN $\alpha-2 a+R B V$, compared to PegIFN $\alpha-2 a+R B V$ alone. No historical comparisons were possible for cutaneous events such as rash and/or pruritus. Data from RCTs in non-HIV patients on cutaneous events associated with simeprevir are heterogeneous. While two studies reported no differences between simeprevir and placebo (PROMISE, QUEST-1), two other trials reported a higher frequency of rash and photosensitivity (QUEST-2) or rash (ASPIRE) in the simeprevir group.

Treatment recommendations for chronic hepatitis C have changed dramatically during the last few years, based on the availability of new direct acting antiviral agents such as telaprevir, boceprevir, simeprevir, sofosbuvir, and daclatasvir. According to current guidelines for the treatment of patients with $\mathrm{HCV}-1 / \mathrm{HIV}$ coinfection published by the American Association for the Study of Liver Diseases (AASLD) [28], simeprevir + PegIFNa-2a + RBV is recommended as an alternative regimen for treatmentnaïve or treatment experienced (prior PEG/RBV relapse) HIV/HCV- coinfected patients with genotype 1 who are eligible to receive IFN. The World Health Organization (WHO) Guideline [29] mention PegIFNo-2a + RBV alone or in combination with simeprevir, telaprevir or boceprevir as potential treatment options; and the guideline of the European Association for the Study of the Liver (EASL) [30] recommends simeprevir + PegIFN $\alpha-2 a+R B V$ as one of the six treatment options for HCV-1 infected patients. In contrast to earlier findings of lower SVR rates in HIV/ $\mathrm{HCV}$ - coinfected patients, treatment response to triple therapy or new interferon-free regimens is now comparable to those observed in patients with $\mathrm{HCV}$-monoinfection [30].

For the historical comparison between simeprevir + PegIFN $\alpha-2 a+R B V$ and PegIFN $\alpha-2 a+R B V$ alone, some 
methodological limitations have to be considered. One major limitation is that every historical comparison is subject to potential biases that do not exist for randomized head-to-head comparisons. The evidence from such a comparison is thus always considered to be lower than corresponding evidence from RCTs. Study designs and study populations differed between study $\mathrm{C} 212$ and the trials included for the historical comparison, as well as among the historical studies. As a consequence, factors associated with the study outcome that differed between study C212 and the historical studies may have confounded the results. No trial was identified that exactly matched the study design of study C212. Main differences were the duration of PegIFN $\alpha-2 a+$ RBV treatment and the daily dose of RBV. Because of anticipated drugdrug interactions between commonly used HIV nucleosides and ribavirin, initial trials investigated lower ribavirin doses $(600 \mathrm{mg}$ starting dose in the ACTG trial [12], $800 \mathrm{mg}$ in APRICOT [19]). Subsequent European studies [16] showed markedly improved $\mathrm{HCV}$ cure rates after using weight adapted ribavirin. This was, however, not demonstrated in the controlled randomized trial which investigated different ribavirin dosages [21], so that the actual influence of ribavirin dose on SVR rates remains unclear. In addition, random effects meta-analyses were used to take into account between-study variation of results. As no meta-regression analysis was performed, no conclusions regarding the impact of potential confounding factors on the outcomes of interest could be made. However, the superiority of simeprevir + PegIFN $\alpha-2 a+R B V$ over PegIFN $\alpha-2 a+$ RBV alone was not only evident for the comparison with the meta-analysis results, but also for all but one possible comparisons with the individual studies (excluding one study with $N=10$ participants). In addition, sensitivity analyses were performed for SVR24 in which only trials with a treatment duration at least as long as in study C212 and with the same weight-adapted RBV dose were included. The results were very similar, indicating that these characteristics did not substantially bias the historical comparison for the efficacy measure. Study C212 included patients with previous PegIFNo-2a/RBV treatment, while the historical trials did not or did not report on that aspect. However, for SVR24 this was most likely conservative with respect to the comparison of simeprevir + PegIFN $\alpha-2 a+R B V$ with PegIFN $\alpha-2 a+R B V$ alone, as SVR24 in study C212 was lower for patients with previous PegIFN $\alpha-2 a / R B V$ treatment than for treatment naïve patients. Results regarding AEs from the historical comparison have to be interpreted with special caution, as differences in study design, treatment duration, and/or HIV background therapy may have influenced the proportion of patients with these events. It is difficult to conclude in which direction (i.e. higher or lower risk) the effect measures might were biased by the combination of these study differences. The finding of a lower number of patients who interrupted treatment due to an $\mathrm{AE}$ with sime-

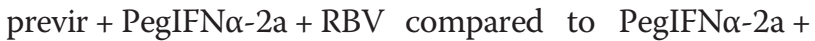
RBV alone was based on one historical study and should be interpreted with caution.

However, the study also has important strengths. The historical comparison was based on a systematic review of available evidence for the treatment efficacy of PegIFN $\alpha-2 a+R B V$ in $\mathrm{HCV}-1 / \mathrm{HIV}$ coinfected patients. Meta-analyses methods to combine the available evidence were used instead of using a single study for a historical comparison. The main results for SVR24 did not depend on the type of meta-analysis model used (fixed or random effects) and were stable in sensitivity analyses that tended to underestimate the treatment difference between simeprevir + PegIFN $\alpha-2 a+$ RBV and PegIFN $\alpha-2 a+$ RBV alone.

\section{Conclusions}

This historical comparison provides first systematic evidence for the superiority of simeprevir + PegIFN $\alpha-2 a+$ RBV compared to PegIFN $-2 a+$ RBV alone in patients with HCV-1 and HIV coinfection. The absolute difference of the proportion of patients with SVR24 was approx. $45 \%$, which is compatible with data from simeprevir RCTs that included non-HIV patients with HCV1 infection. No increases in the frequency of important AE categories were identified, however these analyses were limited methodologically and by the low number of studies contributing data to these comparisons. Additional data (for instance from observational studies) on the safety of simeprevir triple therapy compared to PegIFN $\alpha-2 a+R B V$ alone and compared to other HCV treatment options would be desirable.

\section{Additional files}

\section{Additional file 1: Electronic search strategy for Medline.}

(DOCX $16 \mathrm{~kb}$ )

Additional file 2: Additional data on meta-analyses and historical comparisons. (DOCX $18 \mathrm{~kb}$ )

\section{Abbreviations}

AASLD: American Association for the Study of Liver Diseases; AE: Adverse event; b.i.d.: bis in die = twice a day; C212: TMC435-TiDP16-C212;

$\mathrm{Cl}$ : confidence interval; EASL: European Association for the Study of the Liver; EMBASE: Excerpta Medica Database; HAART: highly active antiretroviral

therapy; HCV: hepatitis C virus; HCV-1: hepatitis C virus with genotype 1; HIV1: human immunodeficiency virus-type 1; IFN: Interferon; PegIFNa: pegylated interferon alfa; PRISMA: Preferred Reporting Items for Systematic Reviews and Meta-Analyses; q.d.: quaque die = once a day; RBV: ribavirin; RCT: randomized controlled trial; SVR: sustained virologic response; SVR12: sustained virologic response 12 weeks after end of treatment; SVR24: sustained virologic

response 24 weeks after end of treatment; WHO: World Health Organization.

\section{Competing interests}

The study C212 and the historical comparison was funded by Janssen Infectious Diseases-Diagnostics. Xcenda $\mathrm{GmbH}$ received financial support for 
the study. FA received consultancy fees from Xcenda GmbH for performing the analyses and writing the manuscript. AC and WK are employees of Xcenda GmbH. JM is an employee of Janssen K.K. JKR declares that he had no competing interests. The sponsor of the historical comparison (Janssen) proposed this study and writing and submission of the manuscript. Janssen had the right to review and comment all study documents including the manuscript. Data collection, analysis, and interpretation were done by the authors independently from the sponsor.

\section{Authors' contributions}

FA, JM and WK designed the study. The literature search was performed by AC. Relevant studies were selected by FA and AC. FA extracted the study data, performed the statistical analyses, and drafted the study report and the manuscript. WK assisted with drafting the study report and manuscript and provided expertise to the definition of inclusion and exclusion criteria for study eligibility. JM and JKR reviewed the manuscript and provided expertise to the interpretation of results and methodological aspects of the study. All authors read and approved the final manuscript.

\section{Acknowledgements}

The authors thank all patients and their families for participating in study C212.

\section{Author details}

'Charité - University Medicine Berlin; Institute for Social Medicine, Epidemiology and Health Economics, 10098 Berlin, Germany. ${ }^{2}$ Frank Andersohn Consulting \& Research Services, Mandelstr. 16, 10409 Berlin, Germany. ${ }^{3}$ Xcenda GmbH, Lange Laube 31, 30159 Hannover, Germany. ${ }^{4}$ Janssen K.K., Tokyo, Japan. ${ }^{5}$ University of Düsseldorf; Düsseldorf Institute of Competition Economics (DICE), Universitätsstraße 1, 40225 Düsseldorf, Germany. ${ }^{6}$ Department of Medicine I, University Hospital Bonn, Sigmund-Freud-Str. 25, 53105 Bonn, Germany.

\section{Received: 3 December 2014 Accepted: 7 December 2015}

\section{Published online: 11 January 2016}

\section{References}

1. Staples CT, Rimland D, Dudas D. Hepatitis C in the HIV (human immunodeficiency virus) Atlanta V.A. (Veterans Affairs Medical Center) Cohort Study (HAVACS): the effect of coinfection on survival. Clin Infect Dis: Off Publ Infect Dis Soc Am. 1999;29:150-4.

2. Rockstroh JK, Mocroft A, Soriano V, Tural C, Losso MH, Horban A, et al. Influence of hepatitis C virus infection on HIV-1 disease progression and response to highly active antiretroviral therapy. J Infect Dis. 2005;192:9921002.

3. Graham CS, Baden LR, Yu E, Mrus JM, Carnie J, Heeren T, et al. Influence of human immunodeficiency virus infection on the course of hepatitis $C$ virus infection: a meta-analysis. Clin Infect Dis : Off Publ Infect Dis Soc Am. 2001:33:562-9.

4. Deng L-P, Gui X-E, Zhang Y-X, Gao S-C, Yang R-R. Impact of human immunodeficiency virus infection on the course of hepatitis $C$ virus infection: a meta-analysis. World J Gastroenterol. 2009;15:996-1003.

5. Feeney ER, Chung RT. Antiviral treatment of hepatitis C. BMJ. 2014; 348:g3308.

6. Sulkowski M, Pol S, Mallolas J, Fainboim H, Cooper C, Slim J, et al. Boceprevir versus placebo with pegylated interferon alfa-2b and ribavirin for treatment of hepatitis C virus genotype 1 in patients with HIV: a randomised, double-blind, controlled phase 2 trial. Lancet Infect Dis. 2013; 13:597-605.

7. Sulkowski MS, Sherman KE, Dieterich DT, Bsharat M, Mahnke L, Rockstroh JK, et al. Combination therapy with telaprevir for chronic hepatitis $C$ virus genotype 1 infection in patients with HIV: a randomized trial. Ann Intern Med. 2013:159:86-96.

8. Dieterich D, Rockstroh JK, Orkin C, Gutiérrez F, Klein MB, Reynes J, et al. Simeprevir (TMC435) With Pegylated Interferon/Ribavirin in Patients Coinfected With HCV Genotype 1 and HIV-1: A Phase 3 Study. Clin Infect Dis : Off Publ Infect Dis Soc Am. 2014:59:1579-87.

9. Moher D, Liberati A, Tetzlaff J, Altman DG. Preferred reporting items for systematic reviews and meta-analyses: the PRISMA statement. J Clin Epidemiol. 2009;62:1006-12.
10. Miller JJ. The Inverse of the Freeman-Tukey Double Arcsine Transformation. Am Stat. 1978:32:138.

11. Barendregt JJ, Doi SA, Lee YY, Norman RE, Vos T. Meta-analysis of prevalence. J Epidemiol Community Health. 2013;67:974-8.

12. Chung RT, Andersen J, Volberding P, Robbins GK, Liu T, Sherman KE, et al. Peginterferon Alfa-2a plus ribavirin versus interferon alfa-2a plus ribavirin for chronic hepatitis C in HIV-coinfected persons. N Engl J Med. 2004;351:451-9.

13. Dahari H, Affonso de Araujo ES, Haagmans BL, Layden TJ, Cotler SJ, Barone AA, et al. Pharmacodynamics of PEG-IFN-alpha-2a in HIV/HCV co-infected patients: implications for treatment outcomes. J Hepatol. 2010;53:460-7.

14. Fuster D, Planas R, Gonzalez J, Force L, Cervantes M, Vilaro J, et al. Results of a study of prolonging treatment with pegylated interferon-alpha2a plus ribavirin in HIV/HCV-coinfected patients with no early virological response. Antivir Ther. 2006:11:473-82.

15. Murphy AA, Herrmann E, Osinusi AO, Wu L, Sachau W, Lempicki RA. Twice weekly PegIFN-alfa $2 a$ and ribavirin results in superior viral kinetics in HIV/ HCV co-infected patients compared to standard therapy. AIDS. 2011;25: 1179-87.

16. Nunez M, Marino A, Miralles C, Berdun MA, Sola J, Hernandez-Burruezo JJ, et al. Baseline serum hepatitis $C$ virus (HCV) RNA level and response at week 4 are the best predictors of relapse after treatment with pegylated interferon plus ribavirin in HIV/HCV-coinfected patients. J Acquir Immune Defic Syndr. 2007:45:439-44

17. Rivero-Juarez A, López-Cortés LF, Camacho A, Torres-Cornejo A, Gordon A Ruiz-Valderas R, et al. HCV Viral Decline at Week 2 of Peg-IFN-Alpha-2a/RBV Therapy as a Predictive Tool for Tailoring Treatment in HIV/HCV Genotype 1 Co-Infected Patients. PLoS ONE. 2014:9, e99468.

18. Torres-Cornejo A, Ruiz-Valderas R, Jimenez-Jimenez L, Abad-Molina C, Gutierrez-Valencia A, Viciana $P$, et al. Impact of the peginterferon-a $2 a$ and ribavirin plasma levels on viral kinetics and sustained virological response in genotype $1 \mathrm{HCV} / \mathrm{HIV}$-co-infected patients with the unfavourable non-CC IL28B genotypes. J Viral Hepat. 2014;21:178-88.

19. Torriani FJ, Rodriguez-Torres M, Rockstroh JK, Lissen E, Gonzalez-Garcia J, Lazzarin A, et al. Peginterferon Alfa-2a plus ribavirin for chronic hepatitis C virus infection in HIV-infected patients. N Engl J Med. 2004; 351:438-50.

20. Tural C, Galeras JA, Planas R, Coll S, Sirera G, Giménez D, et al. Differences in virological response to pegylated interferon and ribavirin between hepatitis $\mathrm{C}$ virus (HCV)-monoinfected and HCV-HIV-coinfected patients. Antivir Ther. 2008:13:1047-55.

21. Rodriguez-Torres $M$, Slim J, Bhatti $L$, Sterling R, Sulkowski M, Hassanein T, et al. Peginterferon alfa-2a plus ribavirin for HIV-HCV genotype 1 coinfected patients: a randomized international trial. HIV Clin Trials. 2012;13:142-52.

22. Mandorfer M, Payer BA, Scheiner B, Breitenecker F, Aichelburg MC, Grabmeier-Pfistershammer $\mathrm{K}$, et al. Health-related quality of life and severity of fatigue in HIV/HCV co-infected patients before, during, and after antiviral therapy with pegylated interferon plus ribavirin. Liver Int. 2014.34:69-77.

23. Jacobson IM, Dore GJ, Foster GR, Fried MW, Radu M, Rafalsky W, et al. Simeprevir with pegylated interferon alfa 2a plus ribavirin in treatment-naive patients with chronic hepatitis C virus genotype 1 infection (QUEST-1): a phase 3, randomised, double-blind, placebo-controlled trial. Lancet. 2014:384: 403-13.

24. Manns M, Marcellin P, Poordad F, de Araujo ESA, Buti M, Horsmans $Y$, et al. Simeprevir with pegylated interferon alfa $2 a$ or $2 b$ plus ribavirin in treatment-naive patients with chronic hepatitis $C$ virus genotype 1 infection (QUEST-2): a randomised, double-blind, placebo-controlled phase 3 trial. Lancet. 2014;384:414-26.

25. Forns X, Lawitz E, Zeuzem S, Gane E, Bronowicki JP, Andreone P, et al. Simeprevir with peginterferon and ribavirin leads to high rates of SVR in patients with HCV genotype 1 who relapsed after previous therapy: a phase 3 trial. Gastroenterology. 2014;146:1669-79.e3.

26. Zeuzem S, Berg T, Gane E, Ferenci P, Foster GR, Fried MW, et al. Simeprevir increases rate of sustained virologic response among treatmentexperienced patients with HCV genotype-1 infection: a phase IIb trial. Gastroenterology. 2014;146:430-41.e6.

27. Kohli A, Shaffer A, Sherman A, Kottilil S. Treatment of hepatitis C: a systematic review. JAMA. 2014;312:631-40.

28. American Association For The Study of Liver Diseases. Recommendations for Testing, Managing, and Treating Hepatitis C. Patients with HIV/HCV 
Coinfection. [http://www.hcvguidelines.org/full-report/unique-patientpopulations-patients-hivhcv-coinfection]

29. World Health Organization. Guidelines for the Screening, Care and

Treatment of Persons with Hepatitis C Infection. Geneva, Switzerland: WHO

Press; 2014

30. European Association for the Study of the Liver. EASL Recommendations on

Treatment of Hepatitis C 2014. [http://files.easl.eu/easl-recommendations-

on-treatment-of-hepatitis-C.pdf]

Submit your next manuscript to BioMed Central and we will help you at every step:

- We accept pre-submission inquiries

- Our selector tool helps you to find the most relevant journal

- We provide round the clock customer support

- Convenient online submission

- Thorough peer review

- Inclusion in PubMed and all major indexing services

- Maximum visibility for your research

Submit your manuscript at www.biomedcentral.com/submit 